УДК 37.032.

DOI: $10.18384 / 2310-7219-2015-4-78-83$

\title{
Синева Л.С.
}

Московский государственный областной университет

\section{МОДЕЛЬ ФОРМИРОВАНИЯ КЛЮЧЕВЫХ ОБРАЗОВАТЕЛЬНЫХ КОМПЕТЕНЦИЙ СТАРШЕКЛАССНИКОВ СРЕДСТВАМИ СЕТИ ИНТЕРНЕТ И РЕЗУЛЬТАТЫ ЕЕ РЕАЛИЗАЦИИ}

Аннотация. В статье поднимается проблема формирования ключевых образовательных компетенций старшеклассников, имеющая центральное значение в современном образовании. Представлена модель формирования вышеназванных компетенций средствами сети Интернет в условиях общеобразовательной школы. Рассматриваются подходы, методы, способы формирования ключевых образовательных компетенций старшеклассников, этапы реализации модели, результаты экспериментальной проверки применения разработанной педагогической модели в учебно-образовательном процессе учащихся 10 классов.

Ключевые слова: ключевые образовательные компетенции, моделирование, педагогическая модель, педагогический потенциал, экспериментальная работа.

\author{
L. Sineva \\ Moscow State Regional University
}

\section{THE MODEL OF KEY EDUCATIONAL COMPETENCES FORMATION OF HIGH SCHOOL STUDENTS THROUGH THE INTERNET AND THE RESULTS OF ITS IMPLEMENTATION}

Abstract. The article raises the problem of key educational competences formation of high school students, which has great importance in modern education. The model of forming the above competencies by means of the Internet resources in a comprehensive school is given. The approaches, methods, and forms of formation of senior schoolchildren's key educational competences are studied. The stages of the model implementation, as well as the results of its experimental verification in the teaching-learning process of pupils 10th grade are given.

Key words: key educational competences, modeling, pedagogical model, pedagogical potential, experimental work.

В условиях информационного общества особое значение для личности приобретает успешное овладение ключевыми компетенциями, связанными с поиском и обработкой необходимой информации, взаимодействием с информационными системами различного уровня. Человек должен приобретать знания самостоятельно, обновлять их, т.е. учиться всю жизнь. Это потребность общества, системы образования и личности школьника. Анализ педагогических исследований в области формирования ключевых компетенций показал, что

(с) Синева Л.С., 2015. 
вопрос недостаточно освещен в отношении учащихся старшей школы, хотя в этот период обучения возможно скорректировать у выпускников уровень сформированности вышеназванных компетенций до требований ФГОС. Стремление найти пути решения указанной проблемы определили цель исследования, которая в теоретическом плане состоит в разработке модели процесса формирования ключевых образовательных компетенций старшеклассников при работе с Интернет-ресурсами, в практическом - в определении содержания и методов такого формирования.

Согласно словарю-справочнику современного общего образования [4, c. 233], моделирование представляет собой воспроизведение педагогических и психологических явлений при помощи идеальных моделей. Работая с построением модели, мы опирались на многообразие подходов и принципов, разработанных современной педагогической наукой. Основанием модели выбраны метапредметный и деятельностный подходы. Согласно Федеральному государственному образовательному стандарту общего образования (2012 г.), учащиеся должны использовать усвоенные знания, учебные умения и навыки, систему ценностных ориентаций для решения теоретических и практических задач, которые возникают в реальной жизни [5]. Использование метапредметного подхода в формировании ключевых компетенций позволяет старшеклассникам освоить метапредметные понятия и обобщить способы действий с предметами, понятиями, схемами, моделями и т.д. Деятельностный подход обеспечивает формирование готовно- сти обучающихся к самообразованию и саморазвитию за счет самостоятельной исследовательской деятельности.

В процессе исследования мы пришли к убеждению, что формирование ключевых образовательных компетенций должно базироваться на комплексном развитии структурных компонентов этих компетенций с использованием педагогического потенциала сети Интернет. Под педагогическим потенциалом мы подразумеваем резерв возможностей, направленных на формирование личности в условиях ее воспитания, обучения и образования. Работа с большими объемами неоднородной информации по разным учебным предметам должна расширить кругозор учащихся, воздействуя на когнитивный компонент компетенций. Высокая наглядность ресурсов за счет рисунков, схем, видео- и аудиоматериалов, имитационных моделей должна активизировать обобщающеаналитическую деятельность, развить визуальную культуру старшеклассников. Разнообразные тренажеры и виртуальные конструкторы, позволяя отрабатывать навыки работы с информационными объектами, овладевать приемами творческой и исследовательской деятельности, должны обеспечить развитие функционального компонента ключевых образовательных компетенций. Порталы и сайты, отражающие ценностные ориентации различных социальных групп, могут способствовать развитию психологического и социального компонентов ключевых образовательных компетенций, формируя у старших школьников ценностные ориентации, навыки общения в виртуальной среде, толерантность, критичность по отношению к 
себе и окружающим. Поиск и использование ресурсов должны способствовать формированию у учащихся готовности к самообразованию, умения определять цели и планы деятельности и самостоятельно анализировать, контролировать и корректировать ее.

Анализ сущности моделирования в педагогических исследованиях позволяет сконструировать модель формирования ключевых образовательных компетенций как систему находящихся во взаимосвязи и обусловливающих функционирование друг друга целевого, содержательного, процессуального и контрольно-диагностического компонентов [3, с. 54].

Целевой элемент модели предполагает развитие структурных компонентов ключевых образовательных компетенций. Старшеклассники приобретут навыки работы с информацией, у них будут сформированы коммуникативные умения, социально поощряемая система ценностей, полиаспектная картина мира, готовность к самообразованию.

Содержательный элемент предлагаемой модели включает принципы ее реализации, функции, содержание, согласованные с целями и задачами. Принцип системности, последовательности требует усвоения знаний в определенном порядке на основе понимания и взаимосвязи. Принцип связи теории с практикой обеспечивает исследование проблем в тесной связи с показом важнейших путей их использования в жизни. В этом случае у обучающихся вырабатывается научный взгляд на жизненные явления, формируется научное мировоззрение. Подбор учебного материала в предлагаемой модели осуществляется на основе метапредметности и практической значимости.

Содержательный компонент модели определяет ее процессуальный элемент, который реализуется в виде форм и методов, направленных на формирование познавательных, логических, коммуникативных, регулятивных учебных действий: 1) консультирование (объяснение, беседы, обучение по алгоритму); 2) семинары (поисковые беседы, проекты, кейсметод); 3) практикумы (лабораторные работы, поисковые беседы, познавательные игры); 4) кружковые занятия (учебные лекции, практические работы, метод управляемых открытий) решение учебных задач на «ученическом» и «алгоритмическом» уровнях $[1$, c. 56].

Критерием результативности выступает уровень сформированности ключевых образовательных компетенций старшеклассников.

Экспериментальная работа по реализации модели формирования ключевых образовательных компетенций, базирующаяся на идее использования педагогического потенциала сети Интернет, проходила в общеобразовательных школах города Подольска. Внедрение разработанной модели проходило в несколько этапов.

На первом этапе осуществлялась подготовка педагогов, принимающих участие в экспериментальной работе по формированию ключевых образовательных компетенций учащихся. Были организованы семинары, круглые столы, мастер-классы, работа творческих групп. В ходе занятий педагоги овладевали метапредметным, деятельностным подходами, диагностическим инструментарием, осмысливали симптомы 
интернет-зависимости у детей. В итоге каждый учитель представил следующие работы:

- информационный пакет, построенный в соответствии со спецификой преподаваемого предмета и включающий: 1) перечень и характеристики основных информационных ресурсов сети Интернет, обеспечивающих формирование знаний учащихся по конкретному учебному предмету. Критерии отбора: качество, полнота представленной информации, доступность и безопасность сайтов; 2) тезаурус по проблемам, которые будут включены в содержание заданий для учащихся (например, для учителей иностранного языка - страноведческий); 3) рекомендации по поиску и отбору нужной информации и особенностям ее визуального представления;

- программу кружковых занятий, содержание которой базировалось на интеграции учебных предметов, а выбор методов и приемов определялся задачей формирования ключевых образовательных компетенций.

На втором этапе преподаватели проводили кружковые занятия по ранее разработанным программам: «Основы общественных наук», «Основы естествознания». На занятиях кружка «Культура работы в сети Интернет» основное внимание уделялось теоретическим основам работы с MS PowerPoint, базовыми графическими редакторами, интернет-браузерами, российскими и мировыми поисковыми системами, интернет-сайтами; внимание старшеклассников акцентировалось на культуре работы в сети Интернет. На практических занятиях учащиеся отрабатывали умения и навыки поиска, оценки, отбора, интер- претации, преобразования, передачи информации.

На третьем этапе, после проведенной педагогами кружковой работы, определялся уровень сформированности ключевых образовательных компетенций старшеклассников. С учетом выявленных проблемных зон в личностном, социальном и интеллектуальном развитии формировались минигруппы (4-6 человек) для выполнения задания в виде тематического проекта, создававшегося с обязательным использованием Интернет-ресурсов. Под руководством педагогов-предметников каждая группа учащихся создавала презентацию на метапредметной основе. Одним из требований к содержанию презентации являлось наличие на последних слайдах выводов по теме. В ходе выполнения задания десятиклассники получали консультации от педагогов-предметников.

Итоговый этап экспериментальной работы предусматривал проведение конференции, на которой старшеклассники выступали со своими проектами, повторную диагностику уровня сформированности ключевых образовательных компетенций и подведение итогов работы на педагогическом совете.

Результативность экспериментальной работы определялась на основе сравнения результатов контрольного этапа $(\mathrm{N}=100)$ с данными констатирующего этапа ( $\mathrm{N}=100)$, полученными с помощью одних и тех же методов исследования. Изучение когнитивного компонента ключевых образовательных компетенций осуществлялось с помощью школьного теста умственного развития, функционального компонента - с помощью ШТУР и теста 
творческой активности, социального и когнитивного компонентов - с помощью тестов творческой активности и ценностных ориентаций М. Рокича [2, с. 15]. Выбор этих методик был обусловлен их высоким коррекционным потенциалом и возможностью исследования разных аспектов личностного развития учащихся для последующего анализа уровня сформированности у них ключевых образовательных компетенций.

Исследованием установлены изменения, произошедшие в содержании когнитивного компонента ключевых образовательных компетенций учащихся. В среднем количество правильных ответов по методике ШТУР в субтестах «Осведомленность» в экспериментальной группе возросло на 5,0 \%. Учащиеся экспериментальной группы лучше отвечают на вопросы по экономике, политике, культурологии, естествознанию по сравнению с учащимися контрольной группы.

Исследованием установлены изменения, произошедшие в содержании функционального компонента ключевых образовательных компетенций. Если на констатирующем этапе учащиеся контрольной и экспериментальной групп с одинаковой успешностью выполняли задания ШТУР на обобщение знаний и выявление закономерности числовых рядов, то на контрольном этапе в экспериментальной группе в субтестах «Обобщение» (часть 5) число правильных ответов составило 50, 84 \% (на 6 \% больше, чем на констатирующем этапе), в «Числовых рядах» (часть 6) - 78,53 \% (на 6,53 \% больше). Учащиеся экспериментальной группы лучше работают с большим и разнообразным объемом информации, выде- ляют главное, формулируют выводы.

Суть изменений, произошедших в функциональном компоненте ключевых образовательных компетенций школьников, заключается в том, что старшеклассники экспериментальной группы лучше, чем учащиеся контрольной группы, справляются с заданиями, представленными в тесте творческой активности. Учащиеся экспериментальной группы лучше преобразуют объекты, находят новое применение знаниям, ориентированы на познание нового («чувство новизны»). Следствием изменений в функциональном компоненте стало развитие таких личностных качеств учеников, как нацеленность на общение, толерантность, критичность по отношению к себе и окружающим, готовность к диалогу в учебной, трудовой, политической деятельности, что свидетельствует и об изменениях в социальном компоненте ключевых образовательных компетенций учеников.

Исследованием установлены изменения, произошедшие в содержании психологического компонента ключевых образовательных компетенций. Суть таких изменений заключается в том, что у учащихся экспериментальной группы более значимыми стали ценности личной жизни (показатели: любовь, наличие хороших и верных друзей), ценности дела (аккуратность, исполнительность, образованность, эффективность в делах), ценности самоутверждения (образованность, эффективность в делах, твердая воля, смелость в отстаивании своего мнения), индивидуалистические ценности (независимость, рационализм, твердая воля, смелость в отстаивании своего мнения), конформистские (воспитанность, 
самоконтроль, широта взглядов).

Исследованием установлено, что учащихся с высоким и средним уровнем сформированности ключевых образовательных компетенций в экспериментальной группе больше, чем в контрольной.

Подводя итоги проведенной работы, мы пришли к следующим выводам:

1. Формирование ключевых образовательных компетенций происходит достаточно результативно при реализации модели, базирующейся на идее использования педагогического потенциала сети Интернет.

2. Формирование ключевых образовательных компетенций обеспечивается реализацией метапредметного и деятельностного подходов.

3. Формирование ключевых образовательных компетенций старшеклассников предполагает такую организацию внеурочной деятельности, в ходе которой учащиеся обобщают, систематизируют знания по различным учебным дисциплинам, находят этим знаниям практическое применение, отрабатывают умения и навыки работы в сети Интернет.

4. Формирование ключевых образовательных компетенций предполагает повышение педагогической квалификации преподавателей школ. Основной задачей повышения квалификации педагогов является овладение знанием о том, как реализовать компетентностный, метапредметный, деятельностный подходы к формированию ключевых компетенций старшеклассников; как конструировать и реализовать содержание процесса формирования таких компетенций средствами сети Интернет.

\section{ЛИТЕРАТУРА:}

1. Беспалько В.П. Слагаемые педагогической технологии. М : Педагогика, 1989. $192 \mathrm{c}$.

2. Леонтьев Д.А. Ценностные представления в индивидуальном и групповом сознании: виды, детерминанты и изменения во времени // Психологическое образование. 1998. № 1. С. 13-25.

3. Симонов В.П. Педагогический менеджмент: 50 НОУ-ХАУ в управлении образовательным процессом. М. : Педагогическое общество России, 1999. 427 с.

4. Тюмасеева 3.И., Богданов Е.Н., Щербак Н.П. Словарь-справочник современного общего образования: акмеологические, валеологические и экологические тайны. СПб, 2004. 464 с.

5. Федеральный государственный образовательный стандарт среднего (полного) общего образования // Российская газета. 2012. 21 июня. 